\title{
A NEW WIDEBAND NEGATIVE-REFRACTIVE-INDEX METAMATERIAL
}

\author{
NOVI ŠIROKOPASOVNI METAMATERIAL Z NEGATIVNIM \\ LOMNIM KOLIČNIKOM
}

\author{
Sikder Sunbeam Islam ${ }^{1}$, Mohammad Rashed Iqbal Faruque ${ }^{1}$, Mohammad Jakir Hossain ${ }^{1}$, \\ Mohammad Tariqul Islam² \\ ${ }^{1}$ Space Science Centre (ANGKASA) \\ 2Universiti Kebangsaan Malaysia, Faculty of Engineering and Built Environment, \\ Department of Electrical, Electronic and Systems Engineering, 43600 UKM, Bangi, Selangor, Malaysia \\ sikder_islam@yahoo.co.uk \\ Prejem rokopisa - received: 2015-06-30; sprejem za objavo - accepted for publication: 2015-12-15
}

doi: $10.17222 /$ mit.2015.144

This paper reveals the design and analysis of a new wideband negative-refractive-index (NRI) metamaterial unit cell. The proposed metamaterial unit-cell exhibits resonance in the C-band and displays negative permittivity and permeability there with a wideband NRI property. It also shows a wider negative peak of the refractive index in the major area of the C-and X-band and minor area of the $\mathrm{S}$ - and $\mathrm{K}_{\mathrm{u}}$-band, and a maximum $3-\mathrm{GHz}$ negative bandwidth was achieved compared to the reference metamaterial. In the basic design, a square-shaped copper resonator was constructed with a metal strip on the FR-4 substrate material. The measured result was presented and it shows good conformity with the simulated result. Moreover, an analysis was performed with the same design by replacing the substrate material with the popular Rogers RT 6010 instead of the FR-4 material and then it shows NRI properties in the C-, X-and $\mathrm{K}_{\mathrm{u}}$-band.

Keywords: metamaterials, negative refractive index, wideband

Članek obravnava zgradbo in analizo osnovne celice novega, širokopasovnega metamateriala z negativnim lomnim količnikom. Predlagana osnovna celica iz metamateriala kaže resonanco v C-pasu in kaže negativno permitivnost ter permeabilnost $z$ lastnostmi NRI širokega pasu. Kaže tudi širši negativni vrh lomnega količnika v večini področja C-pasu in X-pasu in v manjšem področju $\mathrm{S}$-pasu in $\mathrm{K}_{\mathrm{u}}$-pasu. Največja širina negativnega pasu $(3 \mathrm{GHz}$ ) je bila dosežena $\mathrm{v}$ primerjavi $\mathrm{z}$ referenčnim metamaterialom. Osnovna zgradba je bila konstruirana kot bakren rezonator štirikotne oblike, s kovinskim trakom na podlagi iz FR-4 materiala. Predstavljeni so izmerjeni rezultati, ki kažejo dobro ujemanje z rezultati simulacije. Poleg tega je bila izvedena analiza $\mathrm{z}$ enako zgradbo in $\mathrm{z}$ nadomeščanjem podlage s popularnim Rogers RT 6010 namesto FR-4 materialom in prikazane so NRI lastnosti v C-, X- in $\mathrm{K}_{\mathrm{u}}$-pasu.

Ključne besede: metamateriali, negativni lomni količnik, širokopasovnost

\section{INTRODUCTION}

Metamaterials are engineered (at the atomic level) materials that have unique and extraordinary properties not found in nature. A metamaterial as a composite material, usually gains these properties due to the arrangement of its constituents (in a unit cell) rather than individual properties. There are some exotic properties that are not possible with naturally available materials, but can be achieved with metamaterials, like negative permittivity $(\varepsilon<0)$ or negative permeability $(\mu<0)$, negative refractive index, inverted Snell's law, etc. In 1967 the Russian physicist Victor Veselago ${ }^{1}$ predicted that it is possible to develop a material of such reverse characteristics that it will behave opposite to the natural material. It was also stated by him that a material could exhibit a negative refractive index if it gains negative permittivity and permeability. Around 30 years later in 2000 D. R. Smith et al. ${ }^{2}$ successfully demonstrated a composite material with such negative properties. Due to these uncommon characteristics it can used in many important applications, like antenna design, EM absorption reduc- tion, electromagnetic cloaking operation, filter deign, sensor design, etc. ${ }^{3-7}$ A metamaterial with both negative permittivity $(\varepsilon)$ and negative permeability $(\mu)$ is called a double-negative (DNG) metamaterial or a negative refractive index (NRI) or negative index material (NIM) or a metamaterial with either permittivity or permeability negative is called a single negative (SNG) metamaterial. However, a metamaterial with the DNG property can only exhibit the negative refractive index property properly. There are many metamaterials found in the literature, but not enough metamaterials with a double negative property are found. However, very few of them were designed to exhibit DNG characteristics in the $\mathrm{C}$-band of the microwave region. H. Benosman et al. ${ }^{8}$ presented a double-negative metamaterial, but their metamaterial was applicable for the $\mathrm{K}_{\mathrm{u}}$-band only. $\mathrm{O}$. Turkmen et al. ${ }^{9}$, showed a metamaterial for X-band operation, but their metamaterial was not double negative. A. Dhouibi et al. ${ }^{10}$, proposed a metamaterial for C-band applications, but they claimed these property for an epsilon negative (ENG) metamaterial. S.S. Islam et al. ${ }^{11}$ designed an S-band metamaterial, but their 
metamaterial was showing ENG properties as well. Moreover, recently in ${ }^{12}$, a DNG material was introduced where a maximum $1.05-\mathrm{GHz}$ bandwidth of the negative refractive index region was claimed.

In this study, a new double-negative metamaterial is revealed that exhibits negative refractive index property in the major region of $\mathrm{C}$ - and X-band of microwave spectra with a wider bandwidth. Commercially available finite-difference time-domain (FDTD) based CST-microwave studio software was used to retrieve the S-parameters for the unit cell. For further investigation, the structure was then designed on a Rogers RT 6010 substrate material instead of FR-4 material and an analysis was performed.

\section{DESIGN AND METHODOLOGY}

Figure 1a shows the geometry of the proposed square-shaped metamaterial unit cell. The proposed metamaterial unit cell consists of a simple square-shaped copper structure with a vertical copper stripe in the middle of the material, all having a thickness of $0.035 \mathrm{~mm}$. The copper strip in the middle was placed in such a way that it maintains an equal gap for the two opposite sides of the metal strip. The outer length and width of the unit cell were denoted by $a=b=10 \mathrm{~mm}$. The width of the square-shaped structure was expressed by $w=1 \mathrm{~mm}$. The tiny gap at the two ends of the metal strip was symbolized as $s=0.5 \mathrm{~mm}$. The length and width $(e)$ of the metal strip were $7 \mathrm{~mm}$ and $1 \mathrm{~mm}$. The distance from the central metal strip to the square border was denoted by, $c=d=3.5 \mathrm{~mm}$.

The structure was designed on a $20 \mathrm{~mm} \times 20 \mathrm{~mm}$ square-shaped FR-4 substrate material having a dielectric constant of 4.3 and a loss tangent of 0.025 . The thickness of the substrate was $1.6 \mathrm{~mm}$. In this study, commercially available finite-difference time-domain

(a)

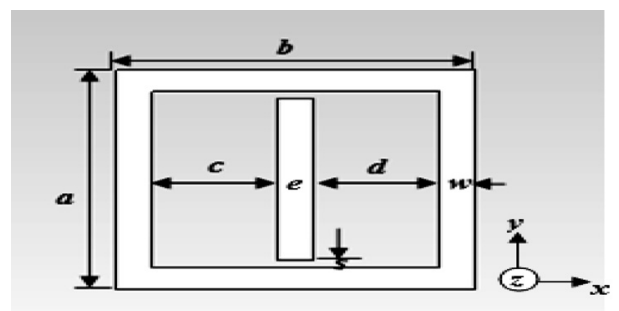

(b)

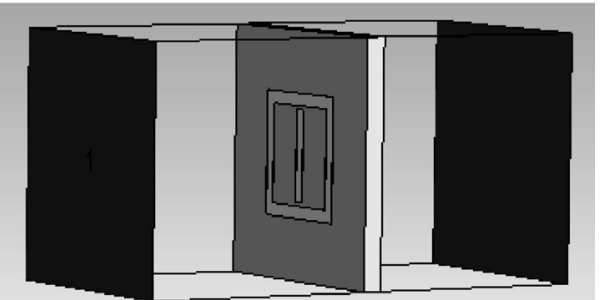

Figure 1: a) Design of the unit cell, b) simulation geometry in CST software

Slika 1: a) Zgradba osnovne celice, b) simulacija geometrije s CST programsko opremo
(FDTD) based computer simulation technology (CST) microwave studio software was adopted for the design and calculation of the reflection $\left(S_{11}\right)$ and transmission $\left(S_{21}\right)$ coefficients of the unit cell. These parameters were used to compute the effective parameters (permittivity, permeability and refractive index) for the unit cell. Figure 1 displays the simulation arrangements. For the simulation, the designed unit cell was placed between two waveguide ports of positive, negative of $z$-axis, and exited by transverse electromagnetic (TEM) waves. The rest of the axes were defined as perfect electric conductor (PEC) and perfect magnetic conductor (PMC) boundary conditions. The frequency-domain solver was used for the whole simulation. The simulation was executed for the frequency range of $1-15 \mathrm{GHz}$. For the computation of the effective parameters, the Nicolson-RossWeir method was utilized to avoid the inverse cosinebranch-index problem. ${ }^{13}$ However, as part of further investigation, the unit cell was rotated by $90^{\circ}$ and the $S$ parameters were estimated for gaining the effective parameters using the same method.

In this study, the open-space measurement technology was adopted. The open-space measurement techno$\operatorname{logy}$ was chosen to observe the realistic effect. For measurement purpose, a prototype of $160 \mathrm{~mm} \times 200 \mathrm{~mm}$ was fabricated that contains $8 \times 10$ unit cell. The fabricated prototype is seen in Figure 2a. The fabricated prototype was placed between two horn antennas. The antennas were acting as the transmitting and receiving end and they were connected to an Agilent E8363D vector network analyzer to calculate the $S$ parameters. However, the distance between the prototype and the horn antenna was kept at $35 \mathrm{~cm}$ to avoid the near-field effect. As a part of calibration process, measurements with and without the prototype were performed as well.

\section{RESULTS AND DISCUSSION}

Figure 2b displays the simulated magnitude of the transmission coefficient $\left(S_{21}\right)$ for the $z$-axis wave propagation through the unit cell. It is evident from Figure $\mathbf{2 b}$ that for the $z$-axis wave propagation a clear resonance is seen in the range of the C-band at the frequency of $7.48 \mathrm{GHz}$ of the microwave spectra. Figure $2 \mathrm{c}$ shows the measured magnitude of the transmission coefficient where it has been compared with the simulated one. It is apparent from Figure $2 \mathbf{c}$ that the measured result shows almost good conformity with the simulated result. However, a slight distortion is found in the measured magnitude of $S_{21}$ than the simulated result that might have occurred due to the noise effect in the open-space measurement process and fabrication error.

Figures 3a and $\mathbf{3 b}$ show the real magnitude of the effective permittivity and the permeability against the frequency for the $z$-axis wave propagation through the unit cell. It is clear from Figure 3a that the permittivity curve has two clear resonances at the frequencies of 

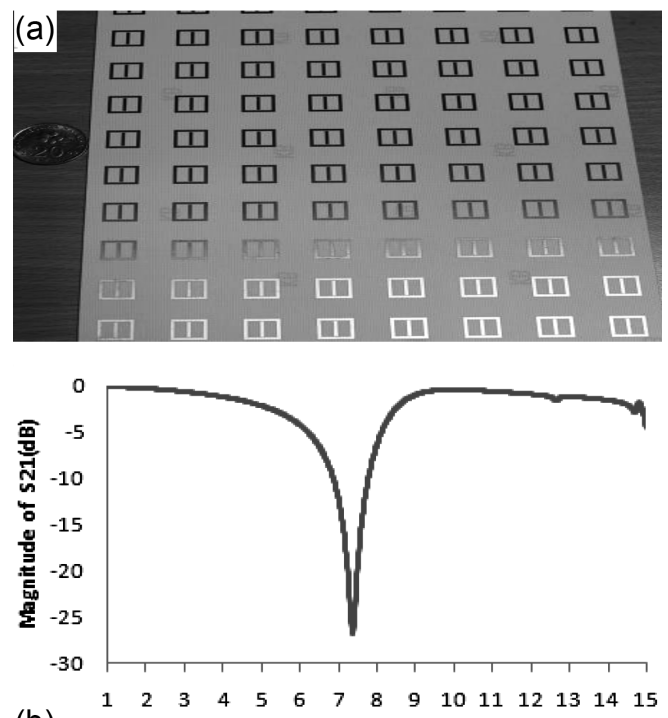

(b)

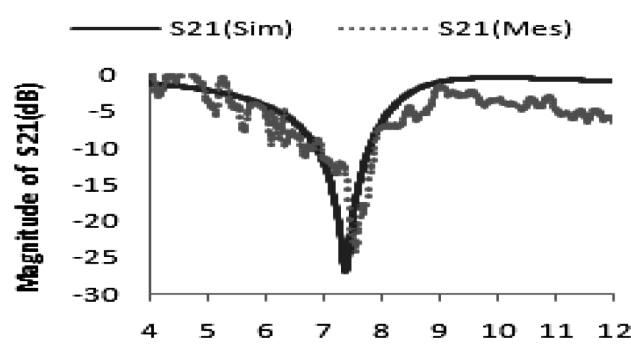

(c)

Figure 2: a) Prototypes for measurement, b) simulated transmission coefficient $\left(S_{21}\right)$ for $z$-axis wave propagation, c) comparision of measured and simulated result for $S_{21}$

Slika 2: a) Prototipi za merjenje; b) simuliran koeficient prenosa $\left(S_{21}\right)$ pri napredovanju vala po $z$-osi, c) primerjava izmerjenega in simuliranega rezultata za $S_{21}$

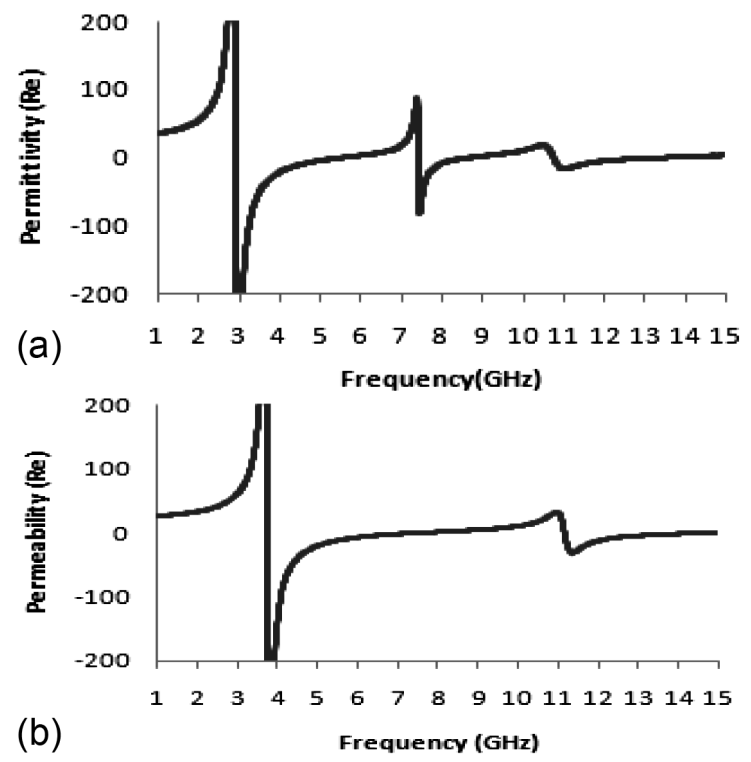

Figure 3: a) Real magnitude of permittivity $(\varepsilon)$ against frequency, b) real magnitude of permeability $(\mu)$ versus frequency

Slika 3: a) Realna magnituda permitivnosti $(\varepsilon)$ proti frekvenci, b) realna magnituda permeabilnosti $(\mu) \mathrm{v}$ odvisnosti od frekvence
$2.94 \mathrm{GHz}$ and $7.45 \mathrm{GHz}$. Moreover, the negative portion of this curve is found from $2.91 \mathrm{GHz}$ to $5.57 \mathrm{GHz}$, which covers almost $2.66 \mathrm{GHz}$ of bandwidth, more than $1 \mathrm{GHz}$ bandwidth from the frequency of $7.42 \mathrm{GHz}$ to $8.71 \mathrm{GHz}$, and nearly $3 \mathrm{GHz}$ bandwidth from the frequency of $10.75 \mathrm{GHz}$ to $13.65 \mathrm{GHz}$. Similarly, the permeability curve of Figure $\mathbf{3 b}$ displays a negative region from the frequency of $3.74 \mathrm{GHz}$ to $7.51 \mathrm{GHz}$ that covers almost $3.77 \mathrm{GHz}$ bandwidth. Another negative portion is visible there from the frequency of $11.15 \mathrm{GHz}$ to $14.77 \mathrm{GHz}$, which also covers nearly $3.62 \mathrm{GHz}$ bandwidth.

For this design, for the varying magnetic field, a charge builds up in the gaps between the metal strip and the ring. At low frequency the current remains in phase with the applied field, but at higher frequency it starts lagging and produces a negative permeability at that frequency.

Figure 4 reveals the real magnitude of the refractive index $(\eta)$ against frequency for the unit cell. In this paper, it was mentioned earlier that for a material the refractive index curve would be negative if its permittivity and permeability curve appears negative simultaneously. Therefore, from Figure $\mathbf{4}$ it is apparent that for the proposed material the refractive index curve exhibits a negative magnitude from the frequency of $3.74 \mathrm{GHz}$ to $5.57 \mathrm{GHz} ; 7.42 \mathrm{GHz}$ to $7.51 \mathrm{GHz}$ and $11.15 \mathrm{GHz}$ to $13.65 \mathrm{GHz}$. It is notable that two wide bandwidths of $1.83 \mathrm{GHz}(3.74 \mathrm{GHz}$ to $5.57 \mathrm{GHz})$ and $3.73 \mathrm{GHz}(11.15 \mathrm{GHz}$ to $13.65 \mathrm{GHz})$ are seen as the negative region in the refractive index curve. These bandwidths have fallen in the few portion of S- and $\mathrm{K}_{\mathrm{u}}$-band and major portion of $\mathrm{C}$ - and $\mathrm{X}$-band of the microwave region.

Moreover, in these negative regions of the refractive index curve, the permittivity and permeability curve are also found to be displaying a negative peak. As a result, the material can be characterized as a double-negative (DNG) metamaterial in these regions of microwave spectra. Another important feature is in the frequency range between $7.42 \mathrm{GHz}$ and $7.51 \mathrm{GHz}$ where the refractive index curve was found to be negative, both the simulated and measured transmittance $\left(S_{21}\right)$ are also found to be exhibiting sharp resonance clearly at the frequency of $7.48 \mathrm{GHz}$ with a refractive index $\eta=-4.40$. Thus, it

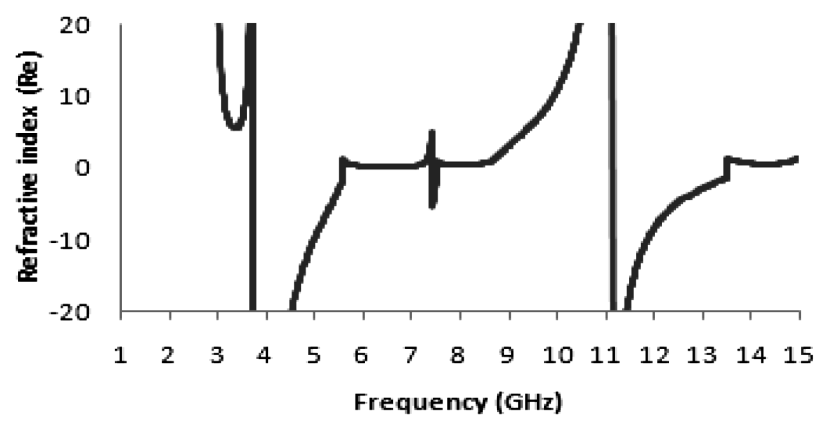

Figure 4: Real magnitude of refractive index $(\eta)$ versus frequency Slika 4: Realni obseg lomnega količnika $(\eta)$ v odvisnosti od frekvence 

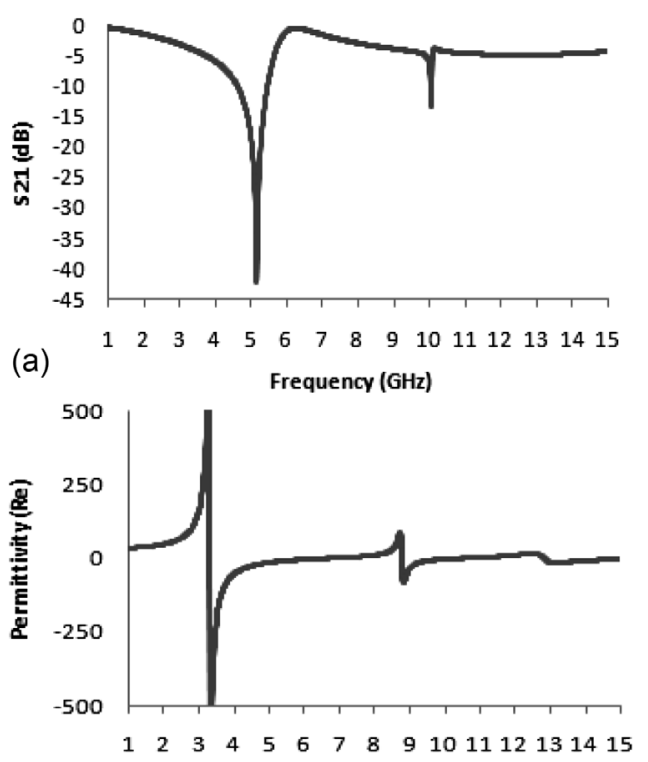

(b)

Frequency $(\mathrm{GHz})$

Figure 5: a) Transmission coefficient $\left(S_{21}\right)$ for the unit cell on the Rogers 6010 substrate material, b) real magnitude of permittivity $(\varepsilon)$ against frequency for the unit cell on the Rogers 6010 substrate

Slika 5: a) koeficient prenosa $\left(S_{21}\right)$ osnovne celice na podlagi iz materiala Rogers 6010 , b) realna magnituda dielektrične konstante $(\varepsilon)$ v odvisnosti od frekvence osnovne celice na podlagi iz Rogers 6010

reveals that for the $z$-axis wave propagation the material is practically applicable for C-band applications in the the microwave spectra.

As a part of a further investigation, the Rogers 6010 substrate material was used instead of the FR-4 substrate material for the unit cell. Figures $\mathbf{5} \mathbf{a}$ and $\mathbf{5 b}$ depicts the transmission coefficient as well as the real magnitude of permittivity $(\varepsilon)$ against frequency for the unit cell on the Rogers 6010 substrate material consecutively.

According to Figure 5a, the transmission coefficient shows two resonances at the frequencies of $5.14 \mathrm{GHz}$ and $10.06 \mathrm{GHz}$. These frequencies are in the range of C-band and X-band. The permittivity curve in Figure 5b reveals a negative magnitude from the frequency of 3.29 $\mathrm{GHz}$ to $6.55 \mathrm{GHz}$, which covers more than $3 \mathrm{GHz}$ bandwidth in the C-band. Similarly, it also shows negative peak from the frequency of $8.80 \mathrm{GHz}$ to $10.30 \mathrm{GHz}$ in the X-band and $12.84 \mathrm{GH}$ to $15 \mathrm{GHz}$ in the Ku-band. In Figures $6 \mathbf{a}$ and $\mathbf{6 b}$ the real magnitude of the permeability and refractive index is depicted. It is apparent from Figure 6a that the permeability curve shows a negative peak from the frequency of $4.33 \mathrm{GHz}$ to 8.90 $\mathrm{GHz}$ and $13.25 \mathrm{GHz}$ to $15 \mathrm{GHz}$. Therefore, from the permittivity and permeability curve of Figures $5 \mathbf{b}$ and $\mathbf{6 a}$ it is evident that the material exhibits a double-negative property from the frequency of $4.33 \mathrm{GHz}$ to $6.55 \mathrm{GHz}$, $8.80 \mathrm{GHz}$ to $8.89 \mathrm{GHz}$ and $13.25 \mathrm{GHz}$ to $15 \mathrm{GHz}$.

Usually, the properties of permittivity and permeability are most likely affected by the polarization due to the internal architecture of the material. When electromagnetic waves enter anisotropic materials, which have
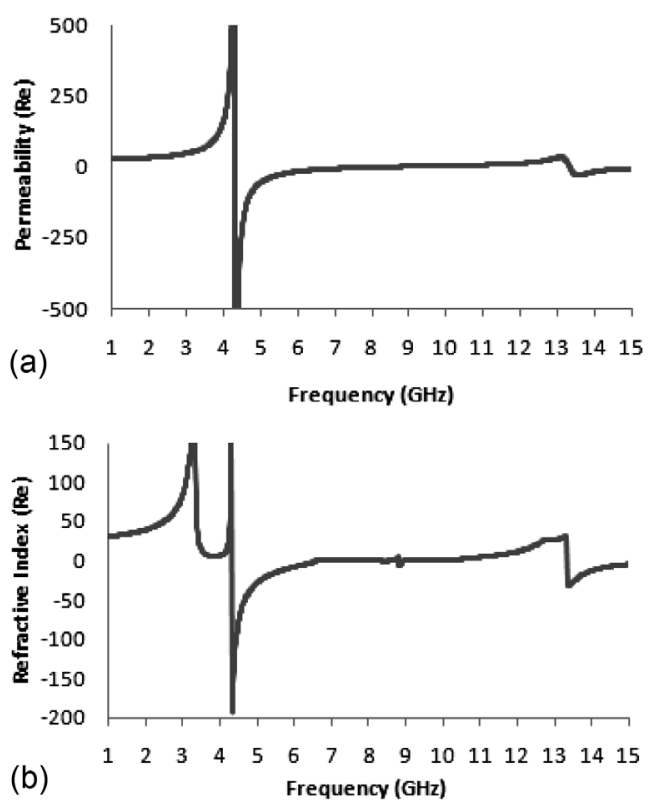

Figure 6: a) Real magnitude of permeability ( $\mu$ ) against frequency, b) real magnitude of refractive index $(\eta)$ versus frequency for the unit cell on the Rogers 6010 substrate material

Slika 6: a) Realen obseg magnitude permeabilnosti $(\mu)$ v odvisnosti od frekvence, b) realen obseg lomnega količnika $(\eta) \mathrm{v}$ odvisnosti od frek-

unequal lattice axes, it is affected by the polarization inside the material. As a result, the value of the permittivity and permeability changes due to changes in the design. In the same way, the refractive index curve is also affected by the polarization.

Similarly, in the refractive index curve in Figure $\mathbf{6 b}$, it is clear that the curve shows negative magnitude from the frequency of $4.33 \mathrm{GHz}$ to $6.55 \mathrm{GHz}, 8.80 \mathrm{GHz}$ to $8.89 \mathrm{GHz}$ and $13.32 \mathrm{GHz}$ to $15 \mathrm{GHz}$ and these frequency ranges cover $2.22 \mathrm{GHz}, 9 \mathrm{MHz}, 2.32 \mathrm{GHz}$ bandwidth in the microwave ranges. These regions of negative refractive index curve fall in the range of $\mathrm{C}, \mathrm{X}$ and $\mathrm{K}_{\mathrm{u}}$-band of microwave spectra. Moreover, these frequencies obey the permittivity and permeability curves in Figures $\mathbf{5 b}$ and 6a as well.

\section{CONCLUSIONS}

In this paper, a new square-shaped negative refractive index metamaterial was demonstrated that exhibits a wider negative peak in the major area of the $\mathrm{C}$-and $\mathrm{X}$-band and the minor area of $\mathrm{S}$ - and $\mathrm{K}_{\mathrm{u}}$-band. A more than $3-\mathrm{GHz}$ wider bandwidth of the negative peak was achieved for the proposed metamaterial than the latest reference metamaterial. The measured result also agrees well with the simulated result. Moreover, the material shows a negative refractive index zone in the $\mathrm{C}$-, $\mathrm{X}$ and $\mathrm{K}_{\mathrm{u}}$-band of the microwave spectra as well as when it is designed on the Rogers 6010 substrate material. However, C- and X-, $\mathrm{K}_{\mathrm{u}}$-band are widely used for long-distance and satellite communications. So, this metamaterial can be practically applied in these frequency bands, 
especially for wider bandwidth application besides the other metamaterials in the microwave range.

\section{REFERENCES}

${ }^{1}$ V. G. Veselago, The electrodynamics of substances with simultaneously negative values of $\varepsilon$ and $\mu$, Soviet Physics Uspekhi, 10 (1968), 509-514, doi:10.1070/PU1968v010n04ABEH003699

${ }^{2}$ D. R. Smith, W. J. Padilla, D. C. Vier, S. C. Nemat-Nasser, S. Schultz, Composite medium with simultaneously negative permeability and permittivity, Physical Review Letters, 84 (2000), 4184-418, doi:10.1103/PhysRevLett.84.4184

${ }^{3}$ S. S. Islam, M. R. I. Faruque, M. T. Islam, An Object-Independent ENZ Metamaterial-Based Wideband Electromagnetic Cloak, Scientific Reports, 6 (2016) 33624, 1-10, doi:10.1038/srep33624

${ }^{4}$ J. Carver, V. Reignault, Engineering of the metamaterial-based cut-band filter, App. Phys. A, 117 (2014), 513-516, doi:10.1007/s00339-014-8694-7

${ }^{5}$ X. Yang, D. Sun, T. Zuo, X. Chen, K. Huang, Analysis and realization of improving the patch antenna gain based on metamaterials, International Journal of Applied Electromagnetics and Mechanbics, 44 (2014) 1, 17-25, doi:10.3233/JAE-131731

${ }^{6}$ L.-W. Li, Y.-N. Li, T. S. Yeo, J. R. Mosig, O. J. F. Martin, A broadband and high-gain metamaterial microstrip antenna, Applied Physics Letters, 96 (2010) 164101, 1-3, doi:10.1063/1.3396984
${ }^{7}$ X. Shen, T. J. Cui, J. Zhao, H. F. W. X. Ma, Jiang, H. Li, Polarization-independent wide-angle triple-band metamaterial absorber, Optical Express, 19 (2011), 9401-9407, doi:10.1364/OE.19.009401

${ }^{8}$ H. Benosman, N. B. Hacene, Design and Simulation of Double "S" Shaped Metamaterial, International Journal of Computer Science Issues, 9 (2012) 2, 534-537, (Available at: http://ijcsi.org/papers/ IJCSI-Vol-9-Issue-2-No-1.pdf)

${ }^{9}$ O. Turkmen, E. Ekmekci, G. Turhan-Sayan, Nested U-ring resonators: a novel multi-band metamaterial design in microwave region, IET Microwave and Antennas Propagation, 6 (2012) 10, 1102-1108, doi:10.1049/iet-map.2012.0037

${ }^{10}$ A. Dhouibi, S. N. Burokur, A. de Lustrac, A. Priou, Study and analysis of an electric Z-shaped meta-atom, Advanced Electromagnetics, 1 (2012) 2, 64-70, doi:10.7716/aem.v1i2.82

${ }^{11}$ S. S. Islam, M. R. I. Faruque, M. T. Islam, Design of a New ENG Metamaterial for S-Band Microwave Applications, Journal of Electrical and Electronics Engineering, 7 (2014) 2, 13-16, (Available at: http://electroinf.uoradea.ro/index.php/jeee.html)

${ }^{12}$ M. I. Hossain, M. R. I. Faruque, M. T. Islam, M. H. Ullah, A New Wide-Band Double-Negative Metamaterial for C- and S-Band Applications, Materials, 8 (2015) 1, 57-71, doi:10.3390/ma8010057

${ }^{13}$ S. S. Islam, M. R. I. Faruque, M. T. Islam, A New Direct Retrieval Method of Refractive Index for Metamaterials, Current Science, 109 (2015) 2, 337-342, (Available at: http://www.currentscience.ac.in/ php/toc.php?vol=109\&issue=02) 